\title{
Where should we draw the lines between dinocyst "species"? Morphological continua in Black Sea dinocysts
}

\author{
Thomas M. Hoyle ${ }^{1}$, Manuel Sala-Pérez ${ }^{2}$, and Francesca Sangiorgi ${ }^{1}$ \\ ${ }^{1}$ Department of Earth Sciences, Utrecht University, Utrecht, 3584 CB, the Netherlands \\ ${ }^{2}$ BRIDGE, School of Geographical Sciences and Cabot Institute, University of Bristol, Bristol, BS8 1SS, UK
}

Correspondence: Thomas M. Hoyle (t.m.hoyle@uu.nl)

Received: 24 October 2018 - Revised: 15 March 2019 - Accepted: 3 April 2019 - Published: 26 April 2019

\begin{abstract}
The morphology of dinoflagellate cysts (dinocysts) is related not only to the genetics of the motile dinoflagellate from which it derives, but is also dependent on a range of environmental factors including salinity, temperature and nutrient status. Although this knowledge improves our understanding of the drivers behind dinocyst morphological variations, it makes the taxonomy governing their description somewhat complex. In basins such as the Black Sea, where environmental change can be extreme and occurs on relatively short (millennial) timescales, taxonomy becomes particularly challenging. Morphological continua can be observed between described forms, displaying a large range of intermediate phenotypes that do not necessarily correspond to any genetic difference. As these morphological nuances may preserve information about palaeoenvironments, it is important to find a systematic method of characterising morphotypes. Here, we show a dinocyst matrix within which dinocysts are described according to their similarity to (or difference from) described forms based on key descriptive parameters. In the example set out here, cyst shape and degree of process and/or ectophragm development are taken as two key parameters in Pyxidinopsis psilata and Spiniferites cruciformis, and can allow the description of intermediate forms even though the definitions do not overlap.

We review some frequently occurring morphotypes and propose that using matrices to show the gradual variation between endmember forms is the most pragmatic approach until cyst-theca studies and genetic sequencing can be used to demonstrate relationships between genotypes and morphotypes. As prior studies propose salinity to be a primary driver of intraspecific variability, the endmembers presented may represent salinity extremes within an overall brackish environment. Although we cannot assign each morphotype to a value or a range of an environmental parameter (e.g. salinity) as the different morphotypes can occur in the same sample, using this matrix allows preservation of information about morphological variability without creating taxonomic categories that are likely to require alteration if genetic evidence becomes available.
\end{abstract}

Organic-walled dinoflagellate cysts (dinocysts) are the resting phase in the life cycle of single celled eukaryotic plankton of the phylum Dinoflagellata (e.g. Fensome et al., 1993; Head, 1996). They can preserve easily in anoxic environments and therefore have potential to retain important biostratigraphic and palaeoenvironmental information (de Vernal and Marret, 2007). Most dinocysts are encountered in marine environments, although they are also produced by dinoflag- ellates in fresh (lake) waters (Evitt et al., 1985; Kouli et al., 2001; McCarthy et al., 2011) and brackish water environments, such as the Sea of Marmara, Black Sea and Caspian Sea (Mudie et al., 2017). Here, surface water parameters such as salinity can be highly variable, from $<1$ psu in the Volga delta to $\sim 30$ psu in the Sea of Marmara (Tuzhilkin and Kosarev, 2005; Yalçın et al., 2017).

Dinocysts' morphological variation in general exhibits a relationship with water properties. In particular, process length variation has been observed to mostly change with 
water density (as a function of salinity and temperature) (Mertens et al., 2011, 2012a). However, other parameters have been mentioned as drivers of intraspecific variation, such as water column deoxygenation (Pross, 2001), temperature and nutrients, which have a relationship with intraspecific cyst body size variation (Mertens, 2013; Mousing et al., 2017). Process development has been considered an environmental adaptation, for example as an aid to clustering in order to promote sinking (Mertens et al., 2009).

Dinocysts from the Black Sea have rather a complex taxonomy due to a combination of factors. They have evolved in a sporadically isolated setting, presenting uncertainties as to their genetic affinities that have only recently been broached (Mertens et al., 2017). They have also been subject to constantly changing environmental conditions (annually and on longer timescales) through recent geological time, a factor that is known to drive variations in cyst morphology (Mertens et al., 2012b; Rochon et al., 2009).

A diverse range of genera, species and subspecies has been described from the Black Sea region, including some potentially endemic forms (Marret et al., 2004; Mudie et al., 2001; Wall and Dale, 1973). The ecological affinities of many of these dinocysts have recently been refined by comparison of surface sample assemblages with measured sea surface conditions, allowing more accurate interpretations of past water column parameters (Mudie et al., 2017). However, problems often arise in the study of Black Sea dinocysts due to the apparent phenotypic plasticity; many morphotypes fall along morphological gradients between formally described species (Wall and Dale, 1973) but cannot correctly be ascribed taxonomically.

Here, we review the morphological variability found in some of the dinocysts retrieved from the late Quaternary of the Black Sea. We provide examples of several undescribed dinocysts and suggest using variability matrices as a method of grouping dinocysts with similar morphologies whilst maintaining morphological information that may be indicative of palaeoenvironments. This approach is suggested here as an alternative to creating unnecessary and potentially misleading taxonomic categories. A strict taxonomic approach, although generally vital in palaeontological work, may not be sufficiently flexible to deal with the morphological plasticity observed in the Black Sea (and the wider Pontocaspian region) during the Quaternary.

We provide an example of how morphotypes may fall along gradients between described taxa and that continua exist between different genera. We have chosen Pyxidinopsis psilata and Spiniferites cruciformis (Wall and Dale in Wall et al., 1973) as endmembers of our review. Despite advancements in modern DNA extraction techniques, obtaining marine plankton DNA from pre-Holocene fossil samples remains challenging due to the tendency for DNA degradation (Boere et al., 2011). We therefore suggest this approach as an alternative to creating artificial taxonomic categories.

\section{Materials and methods}

Thirty-two samples were selected from the Deep Sea Drilling Project (DSDP) Site 379 in the central part of the Black Sea (Location: $43^{\circ} 00.29^{\prime} \mathrm{N}, 36^{\circ} 00.68^{\prime} \mathrm{E}$; at $2165 \mathrm{~m}$ water depth; drilling date: May 1975) (Shipboard Scientific Staff, 1978). Sampling was carried out at the international core repository at the University of Bremen. Sampling was spread across the interval $45-615 \mathrm{~m}$ (of $624.5 \mathrm{~m}$ ), representing the last $\sim 1.2 \mathrm{Ma}$. Details of sampling levels are given in the figure captions and a table is provided in supplementary information which shows all samples and their lithologies according to the original logs (Shipboard Scientific Staff, 1978). The entire record, in combination with other proxies, will be presented in Hoyle (2019), Hoyle et al. (2019) and Bista et al. (2019).

Samples were processed for palynological analysis at Utrecht University using cold $\mathrm{HCl}(30 \%)$ to remove carbonates and cold HF (38\%) to dissolve silicates. Samples were subjected to five minutes in an ultrasonic bath and sieved through meshes (125 and $10 \mu \mathrm{m})$ and the $10-125 \mu \mathrm{m}$ fraction was retrieved. The residues were mounted on slides using glycerine jelly and sealed with lacquer.

Identifications were made using several reference texts (Marret and Zonneveld, 2003; Mudie et al., 2001, 2002, 2017; Rochon et al., 1999, 2002; Shumilovskikh et al., 2013; Soliman and Riding, 2017; Sütô-Szentai, 2000, 2010; Wall and Dale, 1973; Zonneveld et al., 2013).

Transmitted light photographs were taken using a Leica DM2500 LED differential interference contrast microscope with a Leica MC 170 HD camera. Transmitted light photographs were all taken at magnification $\times 630$. Scanning electron microscope (SEM) photographs were taken using a JEOL JCM-6000 benchtop SEM after adhering the palynological residues to a stub and coating with platinum $(6 \mathrm{~nm}$ thick) using a JEOL JFC-2300HR high-resolution fine coater with a JEOL FC-TM20 thickness controller. Examples are taken from representative samples, but the morphotypes observed generally occur throughout the sediment sequence.

\section{Results}

Among the dinocysts retrieved from all the samples analysed, we focus on presenting some selected forms to demonstrate the morphological variability encountered in the late Quaternary sediments (Figs. 1 and 2).

Figure 1 shows transmitted light photographs of several dinocysts that cannot be directly attributable to existing species. Several round cysts with smooth outer walls and precingular archeopyle, resembling Pyxidinopsis psilata (Fig. 1a-c), cannot formally be attributed to Pyxidinopsis psilata sensu stricto due to the presence of incipient processes and/or faint parasutural ornamentation. Dinocyst D (Fig. 1d) is the most extreme form, displaying full processes at least in 
some parts of the cyst, some of which tend to be similar to spines of the genus Spiniferites, but without furcations.

Figure 1e, $\mathrm{f}$ and i show Caspidinium rugosum (Marret et al., 2004) (equivalent to Gonyaulax apiculata of Mudie et al., 2004), displaying variations in ornamentation from classic low, wide parasutural ridges (Fig. 1f), to relatively narrow ridges (Fig. 1i). A noded form of Spiniferites (Fig. 1g) and Impagidinium spp. (Fig. 1h) demonstrate the similarity in tabulation patterns between these two genera, with the main difference being the presence of trifurcate processes on Spiniferites, but absent in Impagidinium.

Figures $1 \mathrm{~m}-\mathrm{p}$ and $2 \mathrm{c}$ show transmitted light and SEM images of variations in cyst form similar to Pyxidinopsis psilata of Soliman and Riding (2017; their plate V, 9-12). However, some of these also closely resemble Komewuia? sp. A (Fig. 1n) and Komewuia? sp. B (Fig. 1o) from the same authors. During our review, we observed a further morphotype with similar wall structure, but no trace of apical or antapical nodes (Figs. 1p and 2e). Figure 2d shows a specimen that most closely resembles the Gonyaulax apiculata cysts of Evitt et al. (1985), but also shows some similarities with the (invalidly described?) Virgodinium asymmetricum primus of Sütő-Szentai (2010; their plate 1, number 1).

Several unknown dinocysts were observed during this review. Figures $1 \mathrm{j}-\mathrm{l}$ and $2 \mathrm{j}-\mathrm{k}$ show Dinocyst sp. A (Figs. $1 \mathrm{j}$ and $2 \mathrm{j}-\mathrm{k}$ ) and Dinocyst B (Fig. $1 \mathrm{k}-1)$. These may represent extreme morphotypes of the genus Spiniferites, but this suggestion is purely speculative. Figures $1 \mathrm{q}-\mathrm{r}$ and $2 \mathrm{i}$ show Dinocyst F. This cyst shows apparent similarity to Galeacysta etrusca (Corradini and Biffi, 1988) with variation in the outline shape of the internal corpus ranging from cruciform to rounded rhomboidal with an ectophragm. However, it cannot be attributed to that genus because the ectophragm of Dinocyst $F$ attaches at the apex and antapex, extending ventrally (and sometimes also dorsally) on the dextral side of the cyst. Galeacysta etrusca, on the other hand, has an appressed endophragm and periphragm in the dorsal region, absent in the region of the sulcus (ventrally). It also appears similar to some forms of Pterocysta cruciformis of Rochon et al. (2002; their plate 2, number 4), although the ectophragm does not appear narrow, wing-like and purely on the ventral side, as per the species description of Rochon et al. (2002). The internal body of this cyst is more similar to Spiniferites cruciformis form 3 and form 4 of Mudie et al. (2001; their plate 1, numbers 2-5). Better images are available in Mudie et al. (2004), our Figs. 1s-t and 2g. Classic Spiniferites cruciformis (form 2 of Mudie et al., 2001) can be seen for comparison in Fig. 2f. Figure 2a shows Impagidinium var. cruciform, a form that often appeared to exhibit a slightly cruciform shape but that has not been formally described. A close up of the apical series can be seen in Fig. 2b, demonstrating the unequal sizes of plate $1^{\prime}$ and $4^{\prime}$. These plates should be of equal size in Impagidinium species, but are unequal in Leptodinium (an extinct genus). Variations on this theme were observed regularly during our review, including specimens with psilate wall structure and squarer cingular plates (e.g. left lateral view in Fig. 2h).

\section{Discussion}

Dinoflagellate cyst morphology is controlled not only by genetics, but also by reaction to environmental stimuli, such as salinity (Mertens et al., 2009, 2012b; Verleye et al., 2012). Changes in these parameters can therefore affect the appearance of cysts so that key features, such as processes, can change morphology, or size, or even disappear completely (Ellegaard et al., 2002).

As key diagnostic characteristics may change in reaction to environmental parameters, dinocysts belonging to the same (cyst based) genus may no longer be attributable unequivocally to that genus once an alteration has occurred. For example, when a cyst attributable to Spiniferites loses its processes it becomes by definition Impagidinium (Mertens et al., 2017). Theoretically and ideally, each specimen should be attributable to one taxon. However, morphological variability due to changing environmental conditions can cause dinocyst specimens to fall into grey areas between definable taxa (Fig. 3). Creating a new species for each defined cyst morphology could be an option. However, this would make for a cumbersome and unwieldy taxonomic system that has the additional disadvantage of not actually relating to genetic species, thereby potentially introducing unnecessary errors.

On the other hand, some specimens that have been attributed to the same (dinocyst based) species are quite different in some aspects. For example, Pyxidinopsis psilata of Wall and Dale in Wall et al. (1973) is generally psilate to scabrate and has quite different ornamentation from the Pyxidinopsis psilata of both Marret et al. (2004) and Soliman and Riding (2017), which tend to show more robust form and sometimes vermiculate ornamentation. Mudie et al. (2017) also show Pyxidinopsis psilata with several variants including possession of an apical horn and with coarse ornamentation. The description of the species Pyxidinopsis psilata allows for a relatively large amount of intraspecific variability (Wall and Dale in Wall et al., 1973). However, the description is also contradictory in places, as: "There are no grooves that might represent either a cingulum or a longitudinal sulcus", but, "atypically, some traces of reflected tabulation are discernible [...] these ridges may reflect parts of a cingulum, an apical, antapical or even a precingular and postcingular series". Although this ambiguity is pragmatic, as it allows a flexible approach to identification in settings where ecophenotypical variation presents problems for taxonomy, grouping of specimens into a category to which they may not usefully belong is erroneous. Such grouping limits the distinction of clearly different morphotypes, such as those shown in Fig. 3a, b, e, f, $\mathrm{i}$ and $\mathrm{m}$. This is especially the case when specimens fall at the very edge of species descriptions, or have been noted as atypical. For example, specimens of Pyx- 

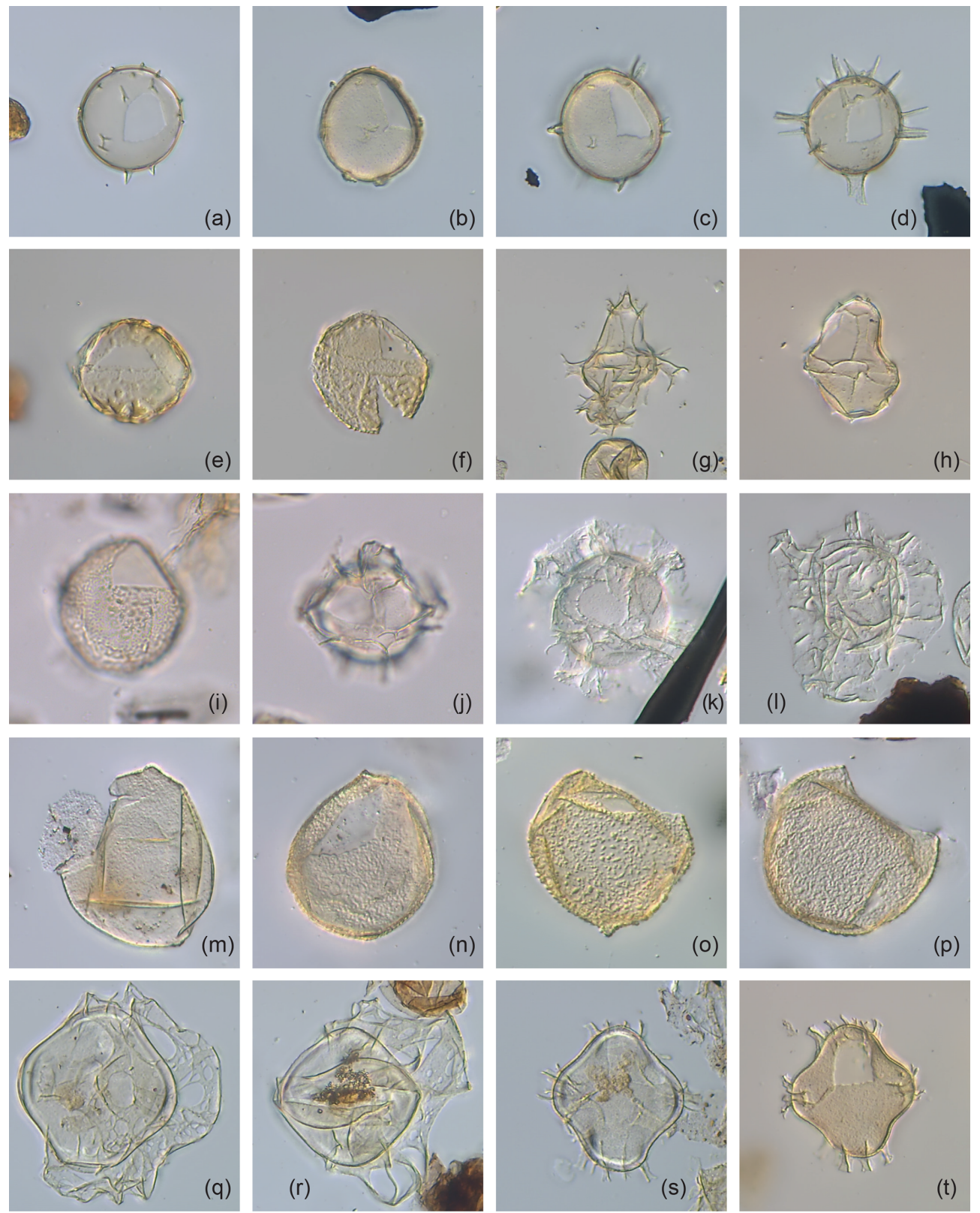

$50 \mu \mathrm{m}$

Figure 1. Examples of the morphotypes observed during the current study by transmitted light microscopy. Sample codes give core number (first number), section number (second number), depth within core (third number, in centimetres) and depth of the middle of the sample in metres below sea floor (mb.s.f.). (a) "Pyxidinopsis psilata? var. A" but with incipient process formation (29-R-1-W, 41-44 cm, 263.93 m b.s.f.). (b) "Pyxidinopsis psilata?" with dome-shaped processes (29-R-1-W, 41-44 cm, 263.93 m b.s.f.). (c) "Dinocyst C" (29-R1-W, 41-44 cm, 263.93 m b.s.f.). (d) "Dinocyst D" (possibly equivalent to extreme version of $P$. psilata? var. A, note antapical flange) (29-R-1-W, 41-44 cm, 263.93 m b.s.f.). (e) Caspidinium rugosum with low, thick paratabular ridges (17-R-1-W, 15-17 cm, 149.65 m b.s.f.). (f) Caspidinium rugosum with low, thick paratabular ridges (17-R-1-W, 15-17 cm, $149.65 \mathrm{~m}$ b.s.f.). (g) Spiniferites $\mathrm{sp}$. (30-R-2-W, 1.5-5 cm, 274.53 m b.s.f.). (h) Impagidinium sp. (17-R-1-W, 15-17 cm, 149.65 m b.s.f.). (i) Variation on Caspidinium rugosum with lighter ornament (13-R-6-W, 100-102.5 cm, 120.41 m b.s.f.). (j) "Dinocyst B” (27-R-3-W, 14-16.5 cm, 247.65 m b.s.f.). (k) "Dinocyst A" (27-R-3-W, 14$16.5 \mathrm{~cm}, 247.65$ m b.s.f.). (l) "Dinocyst A" (27-R-3-W, 14-16.5 cm, 247.65 m b.s.f.). (m) Pyxidinopsis psilata of Soliman and Riding (2017) with apical and antapical notches (52-R-3-W, 91-93.5 cm, 476.42 m b.s.f.). (n) "Pyxidinopsis? Thick wall” with apical notch (52-R-3-W, 91$93.5 \mathrm{~cm}, 476.42 \mathrm{~m}$ b.s.f.). (o) Virgodinioid?/Komewuia? antapical notch (52-R-3-W, 91-93.5 cm, $476.42 \mathrm{~m}$ b.s.f.). (p) "Pyxidinopsis? Thick wall" no notches (52-R-3-W, 91-93.5 cm, 476.42 m b.s.f.). (q) "Dinocyst F" with ectophragm (19-R-4-W, 129.5-133 cm, 174.31 m b.s.f.). (r) "Dinocyst F" with ectophragm (19-R-4-W, 129.5-133 cm, 174.31 m b.s.f.). (s) Spiniferites cruciformis of Mudie et al. (2001) equivalent to Dinocyst F internal corpus with no ectophragm? (19-R-4-W, 129.5-133 cm, $174.31 \mathrm{~m}$ b.s.f.). (t) "Dinocyst F" internal corpus (similar to S. cruciformis form 5 of Mudie et al., 2001) (30-R-2-W, 1.5-5 cm, $274.53 \mathrm{~m}$ b.s.f.). 

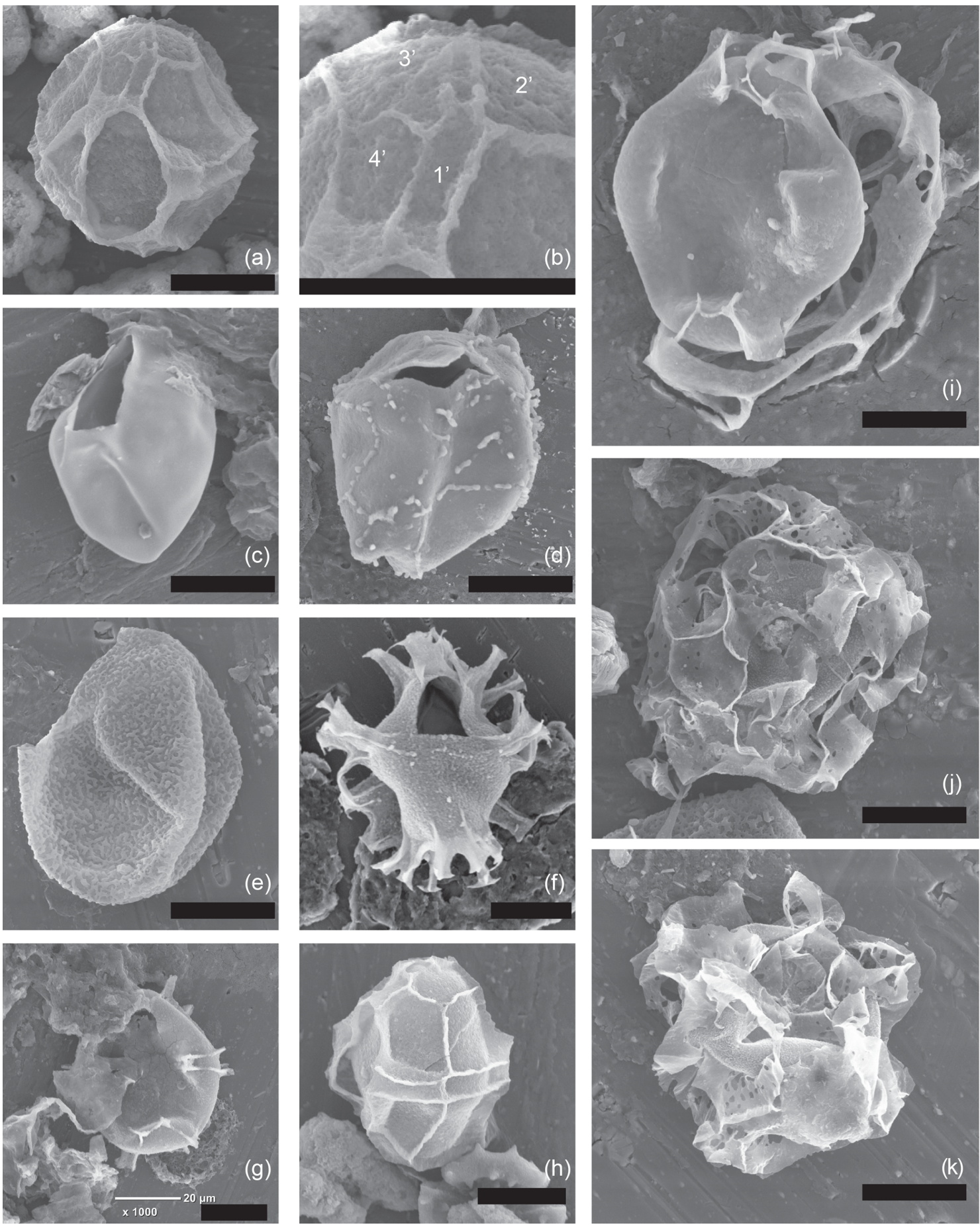

Scale bars $=20 \mu \mathrm{m}$

Figure 2. Examples of the morphotypes observed during the current study by scanning electron microscopy. Sample codes give core number (first number), section number (second number), depth within core (third number, in centimetres) and depth of the middle of the sample in metres below sea floor (m b.s.f.). (a) Impagidinium var. cruciform, refer to (b) for the close-up, which shows mismatch between plates $1^{\prime}$ and 4', (13-R-6-W 100-102.5 cm, 120.41 m b.s.f.). (b) Impagidinium var. cruciform (showing mismatch between plates $1^{\prime}$ and $\left.4^{\prime}\right)(13-\mathrm{R}-6-\mathrm{W}$ 100-102.5 cm, $120.41 \mathrm{~m}$ b.s.f.). (c) Pyxidinopsis psilata of (Wall and Dale, 1973) (20-R-3-W, 95-100 cm, $181.98 \mathrm{~m}$ b.s.f.). (d) Pyxidinopsis? TW/Komewuia? but with suture partly visible (19-R-4-W, 129.5-133 cm, 174.31 m b.s.f.). (e) "Pyxidinopsis? Thick wall” (27-R-3-W 14$16.5 \mathrm{~cm}, 247.65 \mathrm{~m}$ b.s.f.). (f) Spiniferites cruciformis (20-R-3-W, 95-100 cm, $181.98 \mathrm{~m}$ b.s.f.). (g) Spiniferites cruciformis form 4 of Mudie et al. (2001) similar to internal corpus of Dinocyst F (19-R-4-W, 129.5-133 cm, $174.31 \mathrm{~m}$ b.s.f.). (h) Impagidinium var. cruciform (13R-6-W, 100-102.5 cm, 120.41 m b.s.f.). (i) Dinocyst F (19-R-4-W, 129.5-133 cm, 174.31 m b.s.f.). (j) Dinocyst A (27-R-3-W 14-16.5 cm, 247.65 m b.s.f.). (k) Dinocyst A (27-R-3-W 14-16.5 cm, 247.65 m b.s.f.). 


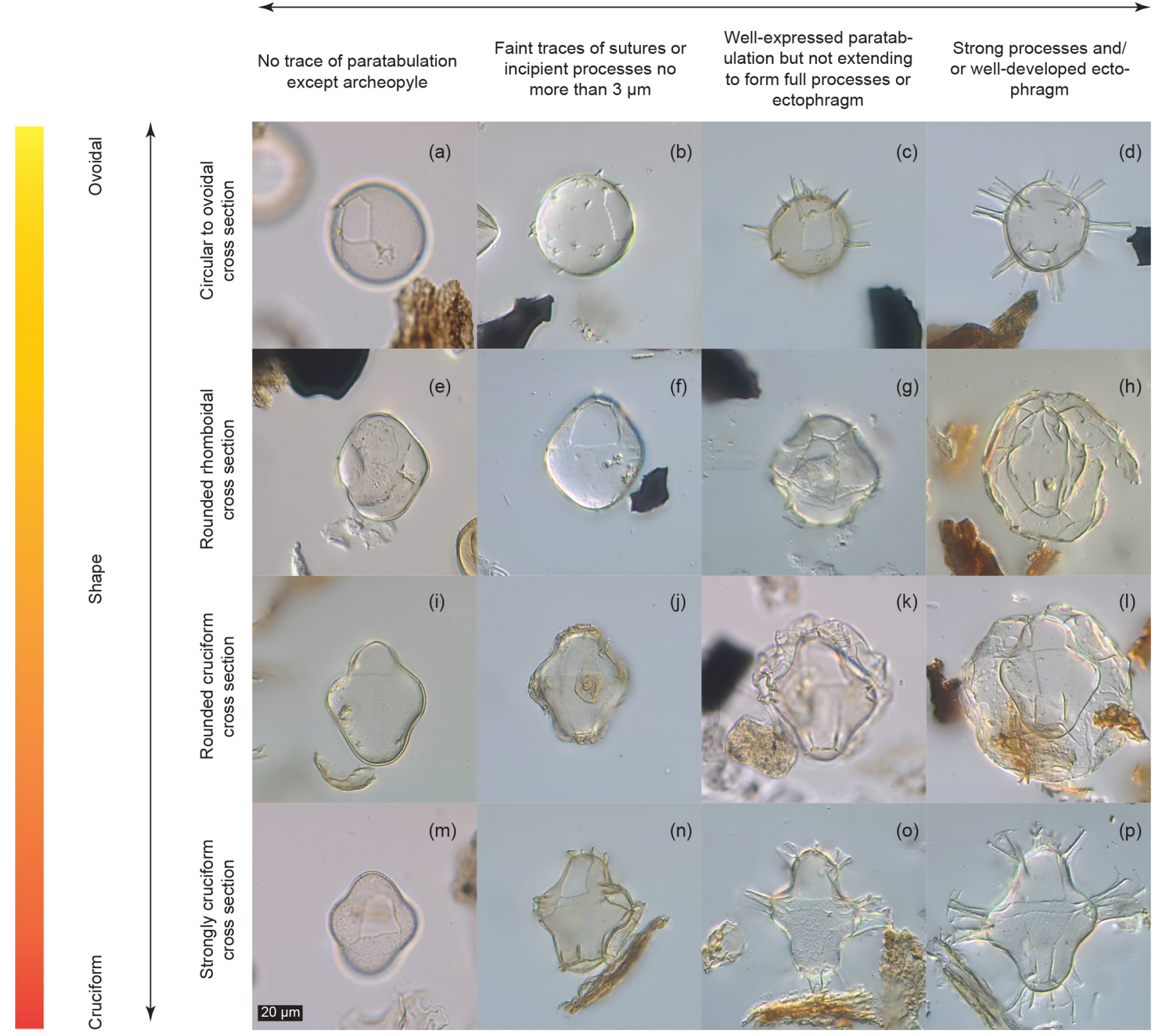

Figure 3. Dinocyst variability matrix showing continua between described forms. Sample codes give core number (first number), section number (second number), depth within core (third number, in centimetres) and depth of the middle of the sample in metres below sea floor (m b.s.f.). (a) Pyxidinopsis psilata (6-R-1-W, 3-5.5 cm, $45.54 \mathrm{~m}$ b.s.f.). (b) "Pyxidinopsis psilata? var. A" (21-R-6-W, 20-23, 195.56 m b.s.f.). (c) Dinocyst C (29-R-1-W, 41-44 cm, 263.93 m b.s.f.). (d) Dinocyst D (29-R-1-W, 41-44 cm, 263.93 m b.s.f.). (e) Pyxidinopsis psilata (12R-2-W, 66.5-69 cm, 104.18 m b.s.f.). (f) "Pyxidinopsis psilata? var. A" rhomboid (8-R-4-W, 9-13 cm, 69 m b.s.f.). (g) Spiniferites cruciformis form 1 of Mudie et al. (2001) or Impagidinium var. cruciform (13-R-6-W 100-102.5 cm, $120.41 \mathrm{~m}$ b.s.f.). (h) Spiniferites cruciformis form 1 of Mudie et al. (2001) (37-R-5-W, 120.5-123 cm, 346.92 m b.s.f.). (i) Pyxidinopsis psilata (6-R-1-W, 3-5.5 cm, 45.54 m b.s.f.). (j) Spiniferites cruciformis form 5 of Mudie et al. (2001) (29-R-1-W, 41-44 cm, $263.93 \mathrm{~m}$ b.s.f.). (k) Spiniferites cruciformis form 4 of Mudie et al. (2001) (14-R-6-W, 131-133.5 cm, 129.03 m b.s.f.). (l) Spiniferites cruciformis form 1 of Mudie et al. (2001) (37-R-5-W, 120.5-123 cm, 346.92 m b.s.f.). (m) Pyxidinopsis psilata (6-R-1-W, 3-5.5 cm, 45.54 m b.s.f.). (n) Spiniferites cruciformis form 5 of Mudie et al. (2001) (29R-1-W, 41-44 cm, 263.93 m b.s.f.). (o) Spiniferites cruciformis form 2 of Mudie et al. (2001) (8-R-4-W, 9-13 cm, 69 m b.s.f.). (p) Spiniferites cruciformis (8-R-4-W, 9-13 cm, 69 m b.s.f.). 
idinopsis psilata with small conical projections (potentially similar to Fig. 3b) are detailed briefly in the description of $P$. psilata, but only as atypical occurrences (Wall and Dale in Wall et al., 1973). Noting and counting unusual or aberrant specimens according to a variability matrix allows the collection of information that would otherwise be neglected. Such information, if recorded routinely can reveal patterns of gradation between described morphotypes and will serve as a framework for the relationship between morphological and species concepts when genetic sequencing of these forms becomes available. Variability matrices may also become useful predictors for palaeoecological trends such as how certain (genetic) species react to environmental change.

In Fig. 3, we present a matrix which we use as a qualitative tool to describe morphological variability. It presents 16 representative cysts that fall along gradients according to two of the most common descriptive parameters used in dinocyst taxonomy: corpus shape (on a $y$ axis gradient, from round to cruciform) and ornamentation (on an $x$ axis gradient, from no ornamentation to heavily developed ornamentation).

Some of the cysts depicted fall within described taxa, such as Pyxidinopsis psilata (Fig. 3a, e, i and m) and Spiniferites cruciformis (Fig. 3o and p). However, other forms clearly have morphological similarities to one (or both) species but may not unambiguously be attributed to either, based on the published descriptions (Head, 1994; Wall et al., 1973). For example, Fig. 3b-d display identical corpora forms and archeopyle configurations to the round form of Pyxidinopsis psilata (Fig. 3a), but differ in their possession of increasingly well-developed processes from left to right. Figure $3 \mathrm{~h}, \mathrm{j}, \mathrm{k}, \mathrm{l}$ and $\mathrm{n}$ show corpora identical to Spiniferites cruciformis but differ in the development of an ectophragm (Fig. 3h, k and 1), or in the truncation of the processes (Fig. $3 \mathrm{j}$ and $n$ ). Other dinocysts in Fig. 3f, g and j do not fit into either of these species descriptions.

The specimen in Fig. 3d ("Dinocyst D") even possesses similar processes to those of Spiniferites cruciformis form 2 of Mudie et al. (2001), yet does not have a cruciform body and it is clearly attributable to neither $S$. cruciformis nor $P$. psilata. Following the diagonal line from top left to bottom right of Fig. 3, it is clear that many configurations are possible on a continuum between described species, and that placement of the boundaries between species is a significant problem. This is especially relevant in Paratethyan and Pontocaspian dinocyst taxonomies due to extreme environmental changes (mostly salinity) through time over longer (million years) and shorter (millennial) timescales, as well as spatial variation, causing the existence of different salinities within basins and in different (but adjacent) basins.

It has already been noted by Head (1994) and Mudie et al. (2017) that some paratypes of Pyxidinopsis psilata could well be the endocysts of Spiniferites cruciformis. While the described species of $S$. cruciformis and $P$. psilata obviously do not intergrade, this is purely an artefact of their (fossilbased) morphological definitions, and in no way does it pre- clude the existence of multiple intermediate morphotypes. This is not altogether surprising given the huge amount of documented variation in both $S$. cruciformis (e.g. Kouli et al., 2001; Marret et al., 2004; Mudie et al., 2001, 2004) and P. psilata (e.g. Mudie et al., 2017; Wall and Dale in Wall et al., 1973).

Matrices demonstrating the full variety of dinocysts present in assemblages according to given observable characteristics, as shown here, provide a useful method for grouping (without the need to construct artificial categories), and provide a systematic approach to simplifying a hugely complex taxonomy. This matrix (Fig. 3) has been designed as an aid to the visualisation of the taxonomic complexity of certain late Quaternary Black Sea dinocysts and to aid description, but it is not intended to infer ecological interpretations. Instead it represents morphological plasticity and serves as a mechanism for grouping and associating forms that are very similar to one another, as well as separating those that are different.

Attempts have been made to establish biometric variants of Galeacysta etrucsca and Spiniferites cruciformis using quantitative methods (Ferguson et al., 2018; Popescu et al., 2009). However, even with the application of statistical approaches, the results appear to support the concept of a morphological continuum with no clear limits between species sub-groups (Popescu et al., 2009). Morphometric approaches such as these are not counter to the matrix approach shown here, but large sample sizes and a high number of whole, wellpreserved dinocysts are nonetheless necessary for their success. Ferguson et al. (2018), for example, used a quantitative approach to differentiate Spiniferites cruciformis from other similar morphotypes, although the outcome was hampered to some degree by sampling constraints (S. cruciformis $n=65$ ), so it is unlikely to represent the full range of morphological variability in S. cruciformis. Matrices provide a qualitative first-order assessment whilst being quick and easy to use. However, ultimately, genetic studies are the only way to draw clear conclusions about the relationship between genotypes and ecophenotypes. Many cysts from the Black Sea and Caspian Sea region have not yet been successfully cultured to produce motile dinoflagellates (Mudie et al., 2017), although such studies are becoming more common (e.g. Lewis et al., 2018; Mertens et al., 2017).

With increased understanding of the functional morphology in dinoflagellates and their cysts (Mertens et al., 2009; Verleye et al., 2012) coupled with a flexible approach to descriptive parameters in dinocysts, along the lines of that applied by Marret et al. (2004) and Mudie et al. (2001), we hope that grouping dinocysts according to the matrix approach will provide a useful tool for palaeoecologists and palynologists working in the Black Sea region.

Consideration must naturally be given to the general useability of such matrices. The matrix proposed by Williams et al. (2015), for example, was opposed by Bijl et al. (2016) on the grounds of practical limitations and that it necessitated the erection and emendation of unnecessary taxa. It was also 
highlighted that Fensome's matrix used a primary characteristic (the shape of the intercalary archeopyle) that was difficult to observe in reality (Bijl et al., 2016; Williams et al., 2015). As such, matrices should not lead to the creation of unnecessary taxa and should preferably define groups based upon characteristics that are observable in the majority of specimens, even when cysts are folded or oriented in an unfavourable direction. Here we suggest that the degree of ornament development (processes and/or ectophragm) and the ambitus (shape in cross section) (especially the degree of concavity in the precingular and postcingular series) are two easily observable characteristics that serve well for grouping or splitting specimens that are otherwise very similar.

To our knowledge, it has never been observed for ecophenotypic variation to be expressed in the paraplate organisation, although archeopyle configuration has been observed to change significantly, even within species (Bijl et al., 2016; Wall, 1967). It is therefore important that the matrix approach should not be seen as a replacement for taxonomy at higher ranks, and the morphological distinctions between families and genera should remain more prominent than those used to distinguish ecophenotypic variants.

A relationship between cyst morphology and the genetics of the motile form cannot simply be assumed without availability of cyst-theca studies and genetic analyses (Mertens et al., 2017). This is because environmental factors also have a significant effect on cyst formation (Ellegaard et al., 2017). It is also not satisfactory to assume that one variable may be entirely responsible for driving species diversity. As we have observed different morphotypes in the same sample during this review, it is possible that certain dinocyst forms are linked to the combination of different environmental parameters (Finkel et al., 2007; Mousing et al., 2017; Pross, 2001). In this case, even where salinity estimates are available, a linear relationship with one particular environmental variable cannot be assumed. Alternatively, the morphology could vary at a timescale shorter than the time represented by a sample (usually 1 or $0.5 \mathrm{~cm}$ thick in a sediment sequence). Use of sediment trap material, or sampling in areas with very high sediment accumulation rates could potentially help developing quantitative analyses of different morphotypes to test for relationships with certain parameters.

\section{Conclusions}

Even with significant advances made over the last 20 years or so (Marret et al., 2004; Mertens et al., 2017; Mudie et al., 2001, 2002, 2017, 2018), the extreme morphological plasticity of the (Quaternary) Black Sea dinocysts represents a constant challenge to environmental reconstructions. Here we have made a review and have presented the idea of using dinocyst variability matrices as a way to draw dividing lines between forms retrieved from sediments in the late Quaternary of DSDP Site 379.
Dedicated cyst-theca studies, in combination with genetic analyses, are still needed to clarify molecular phylogenies and develop full understanding of cyst-theca relationships in many instances (Mertens et al., 2017, 2018). However, until these relationships are known, a pragmatic yet rigorous approach is to adopt and develop dinocyst variability matrices using easily observable traits such as cyst shape, process and ectophragm development. This approach can be user-developed and is an aid to grouping (or splitting) similar (eco-)morphotypes objectively. Crucially, it retains important information on morphological sub-populations without the need for extraneous taxonomic categories, which are likely to require significant alteration if genetic evidence can be obtained.

Data availability. The data associated with this paper are submitted as the Supplement.

Supplement. The supplement related to this article is available online at: https://doi.org/10.5194/jm-38-55-2019-supplement.

Author contributions. TH, MS and FS designed the concept for the paper. TH conducted the microscope work and prepared the paper with contributions from all co-authors.

Competing interests. The authors declare that they have no conflict of interest.

Acknowledgements. This work was part of the PRIDE project, which received funding from the European Union's Horizon 2020 Research and Innovation programme under the Marie SkłodowskaCurie grant agreement no. 642973. Thanks to Martin Head for advice on dinocyst specimens during a microscope session at the British Geological Survey (July 2018). Thanks to Rachel Flecker and Diksha Bista for helpful comments and input during the thought process that preceded the submission of this work. We also thank two anonymous reviewers for their comments.

Review statement. This paper was edited by Luke Mander and reviewed by two anonymous referees.

\section{References}

Bijl, P. K., Brinkhuis, H., Egger, L. M., Eldrett, J. S., Frieling, J., Grothe, A., Houben, A. J. P., Pross, J., Kasia, K. Ś., and Sluijs, A.: Comment on "Wetzeliella and Its Allies - the "Hole" Story: A Taxonomic Revision of the Paleogene Dinoflagellate Subfamily Wetzelielloideae" by Williams et al. (2015)", Palynology, 41, 423-429, 2016. 
Bista, D., Hoyle, T. M., Sangiorgi, F., and Flecker, R.: The connectivity history of the Black Sea over the last 1.2 million years, in preparation, 2019.

Boere, A. C., Rijpstra, W. I. C., De Lange, G. J., Sinninghe Damsté, J. S., and Coolen, M. J. L.: Preservation potential of ancient plankton DNA in Pleistocene marine sediments, Geobiology, 9, 377-393, https://doi.org/10.1111/j.1472-4669.2011.00290.x, 2011.

Corradini, D. and Biffi, U.: Dinocyst study at the MessinianPliocene boundary in the Cava Serredi section, Tuscany, Italy, Bull. des centres Rech. Explor. Elf-Aquitaine, 12, 221-236, 1988.

de Vernal, A. and Marret, F.: Organic-Walled Dinoflagellate Cysts: Tracers of Sea-Surface Conditions, in: Developments in Marine Geology, Proxies in Late Cenozoic Paleoceanography, Vol. 1, edited by: Hillaire-Marcel, C. and de Vernal, A., 371-408, Elsevier, Oxford, 2007.

Ellegaard, M., Lewis, J., and Harding, I. C.: Cyst-theca relationship, life cycle and effects of temperature and salinity on the cyst morphology of Gonyaulax baltica sp. nov. (Dinophyceae) from the Baltic Sea area, J. Phycol., 38, 775-789, 2002.

Ellegaard, M., Dale, B., Mertens, K. N., Pospelova, V., and Ribeiro, S.: Dinoflagellate Cysts as Proxies for Holocene Environmental Change in Estuaries: Diversity, Abundance and Morphology Marianne, in: Applications of Paleoenvironmental Techniques in Estuarine Studies, Developments in Paleoenvironmental Research 20, Vol. 20, edited by: Weckström, K., Saunders, K., Gell, P., and Skilbeck, G., 295-312, Springer, Dordrecht, the Netherlands, 2017.

Evitt, W. R., Gocht, H., and Netzel, H.: Gonyaulax cysts from Lake Zrich sediments, Rev. Palaeobot. Palyno., 45, 35-46, 1985.

Fensome, R. A., Taylor, F. J. R., Norris, G., Sargeant, W. A. S., Wharton, D. I., and Williams, G. L.: A classification of living and fossil dinoflagellates. Micropaleontology, Special publication no. 7, Sheridan Press, Hanover, Pennsylvania, USA, 1993.

Ferguson, S., Warny, S., Escarguel, G., and Mudie, P. J.: MIS 5-1 dinoflagellate cyst analyses and morphometric evaluation of Galeacysta etrusca and Spiniferites cruciformis in southwestern Black Sea, Quaternary Int., 465, 117-129, https://doi.org/10.1016/j.quaint.2016.07.035, 2018.

Finkel, Z. V., Sebbo, J., Feist-Burkhardt, S., Irwin, A. J., Katz, M. E., Schofield, O. M. E., Young, J. R., and Falkowski, P. G.: A universal driver of macroevolutionary change in the size of marine phytoplankton over the Cenozoic, P. Natl. Acad. Sci. USA, 104, 20416-20420, https://doi.org/10.1073/pnas.0709381104, 2007.

Head, M. J.: Morphology and paleoenvironmnental significance of the Cenozoic dinoflagellate genera Tectatodinium and Habibacysta, Micropaleontology, 40, 289-321, 1994.

Head, M. J.: Chapter 30. Modern dinoflagellate cysts and their biological affinities, Palynol. Princ. Appl., 3, 1197-1248, 1996.

Hoyle, T. M.: Biotic Change and Landlocked Seas: Ecosystem responses to climate and sea level variability in the Plio-Pleistocene of the Pontocaspian basins, Utrecht Studies in Earth Sciences, Vol. 177, PhD Thesis, 2019.

Hoyle, T. M., Bista, D., Flecker, R., Krijgsman, W., and Sangiorgi, F.: 400,000 years of climate-driven connectivity changes in the Late Quaternary of the Black Sea, in preparation, 2019.
Kouli, K., Brinkhuis, H., and Dale, B.: Spiniferites cruciformis: A fresh water dinoflagellate cyst?, Rev. Palaeobot. Palyno., 113, 273-286, https://doi.org/10.1016/S0034-6667(00)00064-6, 2001.

Lewis, J., Taylor, J. D., Neale, K., and Leroy, S. A. G.: Expanding known dinoflagellate distributions: investigations of slurry cultures from Caspian Sea sediment, Bot. Mar., 61, 21-31, 2018.

Marret, F. and Zonneveld, K. A. F.: Atlas of modern organic-walled dinoflagellate cyst distribution, Rev. Palaeobot. Palyno., 125, 1200, https://doi.org/10.1016/S0034-6667(02)00229-4, 2003.

Marret, F., Leroy, S. A. G., Chalié, F., and Gasse, F.: New organic-walled dinoflagellate cysts from recent sediments of Central Asian seas, Rev. Palaeobot. Palyno., 129, 1-20, https://doi.org/10.1016/j.revpalbo.2003.10.002, 2004.

McCarthy, F. M. G., Mertens, K. N., Ellegaard, M., Sherman, K., Pospelova, V., Ribeiro, S., Blasco, S., and Vercauteren, D.: Resting cysts of freshwater dinoflagellates in southeastern Georgian Bay (Lake Huron) as proxies of cultural eutrophication, Rev. Palaeobot. Palyno., 166, 46-62, https://doi.org/10.1016/j.revpalbo.2011.04.008, 2011.

Mertens, K. N.: Morphological variation in dinoflagellate cysts: current status and future challenges, in: AASP-CAP-NAMS-CIMPDINO10 joint meeting, San Francisco, USA, 137-137, 2013.

Mertens, K. N., Ribeiro, S., Bouimetarhan, I., Caner, H., Combourieu-Nebout, N., Dale, B., de Vernal, A., Ellegaard, M., Filipova-Marinova, M. V., Godhe, A., Goubert, E., Grøsfjeld, K., Holzwarth, U., Kotthoff, U., Leroy, S. A. G., Londeix, L., Marret, F., Matsuoka, K., Mudie, P. J., Naudts, L., Peña-Manjarrez, J. L., Persson, A., Popescu, S., Pospelova, V., Sangiorgi, F., Van der Meer, M. T. J., Vink, A., Zonneveld, K. A. F., Vercauteren, D., Vlassenbroeck, J., and Louwye, S.: Process length variation in cysts of a dinoflagellate, Lingulodinium machaerophorum, in surface sediments: Investigating its potential as salinity proxy, Mar. Micropaleontol., 70, 54-69, https://doi.org/10.1016/j.marmicro.2008.10.004, 2009.

Mertens, K. N., Dale, B., Ellegaard, M., Jansson, I., Godhe, A., Kremp, A., and Louwye, S.: Process length variation in cysts of the dinoflagellate Protoceratium reticulatum, from surface sediments of the Baltic-Kattegat-Skagerrak estuarine system: a regional salinity proxy, Boreas, 40, 242-255, https://doi.org/10.1111/j.1502-3885.2010.00193.x, 2011.

Mertens, K. N., Bringué, M., Van Nieuwenhove, N., Takano, Y., Pospelova, V., Rochon, A., de Vernal, A., Radi, T., Dale, B., Patterson, R. T., Weckström, K., Andrén, E., Louwye, S., and Matsuoka, K.: Process length variation of the cyst of the dinoflagellate Protoceratium reticulatum in the North Pacific and BalticSkagerrak region: Calibration as an annual density proxy and first evidence of pseudo-cryptic speciation, J. Quaternary Sci. 27, 734-744, https://doi.org/10.1002/jqs.2564, 2012a.

Mertens, K. N., Bradley, L. R., Takano, Y., Mudie, P. J., Marret, F., Aksu, A. E., Hiscott, R. N., Verleye, T. J., Mousing, E. A., Smyrnova, L. L., Bagheri, S., Mansor, M., Pospelova, V., and Matsuoka, K.: Quantitative estimation of Holocene surface salinity variation in the Black Sea using dinoflagellate cyst process length, Quaternary Sci. Rev., 39, 45-59, https://doi.org/10.1016/j.quascirev.2012.01.026, 2012b. 
Mertens, K. N., Takano, Y., Gu, H., Bagheri, S., Pospelova, V., Pieńkowski, A. J., Leroy, S. A. G., and Matsuoka, K.: CystTheca Relationship and Phylogenetic Position of Impagidinium caspienense Incubated from Caspian Sea Surface Sediments: Relation to Gonyaulax baltica and Evidence for Heterospory within Gonyaulacoid Dinoflagellates, J. Eukaryot. Microbiol., 64, 829842, https://doi.org/10.1111/jeu.12417, 2017.

Mertens, K. N., Carbonell-moore, M. C., Pospelova, V., Head, M. J., Highfield, A., Schroeder, D., Gu, H., Andree, K. B., Fernandez, M., Yamaguchi, A., Takano, Y., Matsuoka, K., Nézan, E., Bilien, G., Okolodkov, Y., Koike, K., Hoppenrath, M., Pfaff, M., Pitcher, G., Al-muftah, A., Rochon, A., Teen Lim, P., Pin Leaw, C., Fei Lim, Z., and Ellegaard, M.: Pentaplacodinium saltonense gen. et sp. nov. (Dinophyceae) and its relationship to the cyst-defined genus Operculodinium and yessotoxinproducing Protoceratium reticulatum, Harmful Algae, 71, 57-77, https://doi.org/10.1016/j.hal.2017.12.003, 2018.

Mousing, E. A., Ribeiro, S., Chisholm, C., Kuijpers, A., Moros, M., and Ellegaard, M.: Size differences of Arctic marine protists between two climate periods - using the paleoecological record to assess the importance of within-species trait variation, Ecol. Evol., 7, 3-13, https://doi.org/10.1002/ece3.2592, 2017.

Mudie, P., Rochon, A., Richards, K., Ferguson, S., and Warny, S.: Spiniferites cruciformis, Pterocysta cruciformis and Galeacysta etrusca: morphology and palaeoecology, Palynology, 42, 135161, https://doi.org/10.1080/01916122.2018.1465737, 2018.

Mudie, P. J., Aksu, A. E., and Yasar, D.: Late Quaternary dinoflagellate cysts from the Black, Marmara and Aegean seas: Variations in assemblages, morphology and paleosalinity, Mar. Micropaleontol., 43, 155-178, https://doi.org/10.1016/S03778398(01)00006-8, 2001.

Mudie, P. J., Rochon, A., Aksu, A. E., and Gillespie, H.: Dinoflagellate cysts, freshwater algae and fungal spores as salinity indicators in Late Quaternary cores from Marmara and Black seas, Mar. Geol., 190, 203-231, https://doi.org/10.1016/S00253227(02)00348-1, 2002.

Mudie, P. J., Rochon, A., Aksu, A. E., and Gillespie, H.: Late glacial, Holocene and modern dinoflagellate cyst assemblages in the Aegean-Marmara-Black Sea corridor: Statistical analysis and re-interpretation of the early Holocene Noah's Flood hypothesis, Rev. Palaeobot. Palynol., 128, 143-167, https://doi.org/10.1016/S0034-6667(03)00117-9, 2004.

Mudie, P. J., Marret, F., Mertens, K. N., Shumilovskikh, L. S., and Leroy, S. A. G.: Atlas of modern dinoflagellate cyst distributions in the Black Sea Corridor: From Aegean to Aral Seas, including Marmara, Black, Azov and Caspian Seas, Mar. Micropaleontol., 134, 1-144, https://doi.org/10.1016/j.marmicro.2017.05.004, 2017.

Popescu, S., Dalesme, F., Jouannic, G., Escarguel, G., Head, M. J., Melinte-Dobrinescu, M. C., Sütő-Szentai, M., Bakrač, K., Clauzon, G., and Suc, J. P.: Galeacysta etrusca complex: Dinoflagellate cyst marker of paratethyan influxes to the Mediterranean sea before and after the peak of the messinian salinity crisis, Palynology, 33, 105-134, https://doi.org/10.1080/01916122.2009.9989688, 2009.

Pross, J.: Paleo-oxygenation in tertiary epeiric seas: Evidence from dinoflagellate cysts, Palaeogeogr. Palaeocl., 166, 369-381, https://doi.org/10.1016/S0031-0182(00)00219-4, 2001.
Rochon, A., de Vernal, A., Turon, J.-L., Matthiessen, J., and Head, M. J.: Distribution of recent dinoflagellate cysts in surface sediments from the North Atlantic Ocean and adjacent seas in relation to sea-surface parameters, Am. Assoc. Stratigr. Palynol., 35, 1-146, https://doi.org/10.1016/0377-8398(94)00016-G, 1999.

Rochon, A., Mudie, P. J., Aksu, A. E., and Gillespie, H.: Pterocysta gen. nov.: A new dinoflagellate cyst from pleistocene glacialstage sediments of the black and Marmara Seas, Palynology, 26, 95-105, https://doi.org/10.1080/01916122.2002.9989568, 2002.

Rochon, A., Lewis, J., Ellegaard, M., and Harding, I. C.: The Gonyaulax spinifera (Dinophyceae) "complex": Perpetuating the paradox?, Rev. Palaeobot. Palyno., 155, 52-60, https://doi.org/10.1016/j.revpalbo.2008.12.017, 2009.

Shipboard Scientific Staff: 3. Site 379, in: Initial reports of the Deep Sea Drilling Project, Volume 42, Part 2, edited by: Ross, D. A. and Neprochnov, Y. P., 29-118, U.S. Government Printing Office, Washington, 1978.

Shumilovskikh, L. S., Marret, F., Fleitmann, D., Arz, H. W., Nowaczyk, N., and Behling, H.: Eemian and Holocene sea-surface conditions in the southern Black Sea: Organic-walled dinoflagellate cyst record from core 22-GC3, Mar. Micropaleontol., 101, 146-160, https://doi.org/10.1016/j.marmicro.2013.02.001, 2013.

Soliman, A. and Riding, J. B.: Late Miocene (Tortonian) gonyaulacacean dinoflagellate cysts from the Vienna Basin, Austria, Rev. Palaeobot. Palyno., 244, 325-346, https://doi.org/10.1016/j.revpalbo.2017.02.003, 2017.

Sütô-Szentai, M.: Organic walled microplankton zonation of the Pannonian S.L. in the surroundings of the Kaskantyú, Paks and Tengelic, Hungary, 2000.

Sütő-Szentai, M.: Definition and description of new dinoflagellate genus, species and subspecies from the Pannonian Stage (Hungary), Acta Nat. Pannonica, 1, 223-239, 2010.

Tuzhilkin, V. S. and Kosarev, A. N.: Thermohaline Structure and General Circulation of the Caspian Sea Waters, Handb. Environ. Chem., 5, 33-57, 2005.

Verleye, T. J., Mertens, K. N., Young, M. D., Dale, B., McMinn, A., Scott, L., Zonneveld, K. A. F., and Louwye, S.: Average process length variation of the marine dinoflagellate cyst Operculodinium centrocarpum in the tropical and Southern Hemisphere Oceans: Assessing its potential as a palaeosalinity proxy, Mar. Micropaleontol., 86-87, 45-58, https://doi.org/10.1016/j.marmicro.2012.02.001, 2012.

Wall, D.: Fossil microplankton in deep-sea cores from the Caribbean Sea, Palaeontology, 10, 95-123, 1967.

Wall, D. and Dale, B.: Paleosalinity relationships of dinoflagellates in the late quaternary of the black sea - a summary, Geosci. Man., 7, 95-102, https://doi.org/10.1080/00721395.1973.9989739, 1973.

Wall, D., Dale, B., and Harada, K.: Descriptions of new fossil dinoflagellates from the Late Quaternary of the Black Sea, Micropaleontology, 19, 18-31, 1973.

Williams, G. L., Damassa, S. P., Fensome, R. A., and Guerstein, G. R.: Wetzeliella and its allies - the "hole" story: a taxonomic revision of the Paleogene dinoflagellate subfamily Wetzelielloideae, Palynology, 39, 289-344, https://doi.org/10.1080/01916122.2014.993888, 2015. 
Yalçın, B., Artüz, M. L., Pavlidou, A., Çubuk, S., and Dassenakis, M.: Nutrient dynamics and eutrophication in the Sea of Marmara: Data from recent oceanographic research, Sci. Total Environ., 601-602, 405-424, https://doi.org/10.1016/j.scitotenv.2017.05.179, 2017.

Zonneveld, K. A. F., Marret, F., Verreussel, R., Bogus, K., Bonnet, S., Bouimetarhan, I., Crouch, E., de Vernal, A., Elshanawany, R., Edwards, L., Esper, O., Forke, S., Grøsfjeld, K., Henry, M., Holzwarth, U., Kielt, J. F., Kim, S., Ladouceur, S., Ledu, D., Chen, L., Limoges, A., Londeix, L., Lu, S. H., Mahmoud, M. S., Marino, G., Matsuoka, K., Matthiessen, J., Mildenhal, D. C., Mudie, P. J., Neil, H. L., Pospelova, V., Qi, Y., Radi, T., Richerol, T., Rochon, A., Sangiorgi, F., Solignac, S., Turon, J. L., Verleye, T. J., Wang, Y., Wang, Z., and Young, M. D.: Atlas of modern dinoflagellate cyst distribution based on 2405 data points, Rev. Palaeobot. Palyno., 191, 1-197, https://doi.org/10.1016/j.revpalbo.2012.08.003, 2013. 